\title{
Література:
}

1. Дранко А. А. Формування професійної взаємодії майбутніх пілотів цивільної авіації у процесі наземної практичної підготовки: дис. ... канд. пед. наук: 13.00.04. Кропивницький, 2018. 224 с.

2. Керницький О. М. Методика формування психологічної готовності курсантів-льотчиків до льотної діяльності: автореф. дис. ... канд. пед. наук: 13.00.02. Харків, 2005. 17 с.

3. Плачинда Т. С. Формування емоційної стійкості майбутніх пілотів засобами фізичної і психофізіологічної підготовки / T. С. Плачинда // Вісник Національного авіаційного університету : зб. наук. праць. К.: НАУ, 2011. № 2 (47). С. 170-176.

DOI https://doi.org/10.30525/978-9934-26-173-2-19

\section{ОСОБЛИВОСТІ САМОСТІЙНОЇ РОБОТИ СТУДЕНТІВ МЕДИКІВ 3 ДИСЦИПЛІНИ «МЕДИЧНА ХІМІЯ» В УМОВАХ БОЛОНСЬКОЇ СИСТЕМИ}

\author{
Нечитайло Л. Я. \\ кандидат біологічних наук,
}

асистент кафедри біологічної та медичної хімії ім. ак. Г. О. Бабенка Івано-Франківський національний медичний університет

Кривов'яз О. С.

здобувач $P h D$,

асистент кафедри біологічної та медичної хімї ім. ак. Г. О. Бабенка Івано-Франківський національний медичний університет

Данилів C. I.

кандидат біологічних наук,

асистент кафедри фармацевтичного управління, технологї ліків

та фармакогнозії

Івано-Франківський національний медичний університет

м. Івано-Франківськ, Украӥна

Навчальна дисципліна «Медична хімія» закладає основи вивчення студентами таких медико-біологічних дисциплін як: фізіологія, патофізіологія, біологічна хімія, фармакологія, а також деяких клінічних, гігієнічних дисциплін та екології. Курс медичної хімії в ІФНМУ вивчають студенти медичного та стоматологічного факультетів 
на першому курсі. Метою викладання навчальної дисципліни «Медична хімія» $\epsilon$ формування у студентів знань про основні типи хімічної рівноваги для формування цілісного фізико-хімічного підходу до вивчення процесів життєдіяльності організму, а також вміти застосовувати хімічні методи кількісного та якісного аналізу, вміти класифікувати хімічні властивості та перетворення біонеорганічних речовин в процесі життєдіяльності організму [1, с. 3].

Організація навчального процесу дисципліни «Медична хімія» здійснюється за кредитно-модульною системою відповідно до вимог Європейської кредитної трансферно-накопичувальної системи. Внаслідок запровадження даної системи у навчання вищих медичних закладах посилюється значимість організації та підвищення ефективності самостійної роботи студентів. Згідно з Законом України «Про вищу освіту», самостійна робота визначена як форма організації освітнього процесу у ВНЗ [2].

Самостійна робота - одна 3 основних складових професійної підготовки студентів у ВНЗ, яка сприяє саморозвиткові необхідних здібностей випускника до більш складних видів діяльності, забезпечує формування мобільних, здатних до інноваційної діяльності кваліфікованих кадрів [3, с. 66].

За навчальним планом на вивчення дисципліни «Медична хімія» відведено 4 кредити, тобто 120 годин, 3 них лекційних - 20 годин, 50 годин - практичних занять та 50 годин на самостійну роботу. Дисципліна структурована на два підсумкові модулі, до кожного з яких входить по два змістових модулі. Формою контролю якості знань і навчальної діяльності студентів, є підсумковий модульний контроль (ПМК). Медична хімія, як і будь-яка інша дисципліна містить багато інформації, яку неможливо висвітлити під час аудиторних занять в повному обсязі. В зв'язку з цим виникає необхідність навчити студента самостійно опрацьовувати матеріал. Правильно організувати самостійну роботу студента (СРС), грамотно спрямувати їх на творчий пошук, забезпечивши його методично, - одне 3 найважливіших завдань організації навчального процесу.

Нашою метою $є$ визначення ефективності застосування самостійної роботи під час вивчення дисципліни «Медична хімія» для студентівмедиків.

Відповідно до сучасних освітніх вимог особливе місце в навчальному процесі відводиться самостійній роботі студентів-медиків. Самостійну роботу можна поділити на кілька видів: вона ведеться під час аудиторних занять, під контролем викладача у формі консультацій, 
заліків та іспитів; позааудиторією при виконанні студентами домашніх завдань [4, с. 196].

Самостійна робота включає вивчення окремих тем навчальної програми, що не розглядаються на лекційних, практичних заняттях, але входять до навчальної програми і контролюються під час практичних занять та підсумкового модульного контролю. Обсяг самостійної роботи 3 курсу «Медична хімія» регламентується методичними рекомендаціями, в яких сформульовані мета та завдання для самоконтролю знань, вмінь 3 кожної самостійної роботи студентів. Також розроблений комплекс тестових завдань до кожної $з$ тем навчального матеріалу 3 медичної хімії. Викладачем протягом усього терміну вивчення дисципліни проводиться контроль за процесом позааудиторної самостійної роботи студента. Завдання викладача не лише перевірити та оцінити вивчене студентом, але й допомогти правильно мислити й вирішувати питання. Ініціативних студентів викладачі заохочують додатковими балами $з$ дисципліни. Оцінка позааудиторної СРС здійснюється під час проведення підсумкового контролю, шляхом зарахування додаткових балів із дисципліни.

Організація СРС забезпечується системою навчально-методичних засобів, передбачених для вивчення медичної хімії, зокрема:

- робота 3 навчальною літературою, яка сприяє розширенню кругозору студента. Уміння працювати 3 навчальною літературою $€$ важливим елементом виконання самостійної роботи.

- робота з конспектом лекцій.

- виконання завдань, розв’язування ситуаційних задач.

Важливе місце при вивченні дисципліни відводиться ситуаційним завданням, які поєднують міждисциплінарні зв'язки і розглядаються при виконанні самостійної роботи, розв'язання яких обговорюються на практичному занятті. Це дає можливість оцінити вміння студента вирішувати проблеми, застосовувати знання на практиці.

- підготовка до виконання тестових завдань, що передбачає виконання завдань до самопідготовки кожного практичного заняття, а також комп'ютерне тестування.

- підготовка рефератів, доповідей. Для кращого засвоєння тем пропонується індивідуальні завдання, написання рефератів, доповідей.

Поєднання різноманітних форм і методів самостійної роботи та іiі контролю дозволяє підвищити і активізувати діяльність студентів. Такий підхід дозволяє виявити найуспішніших, здібних та талановитих студентів.

Провідне місце в самостійній роботі студентів-медиків займає використання Інтернет-технологій для ефективного пошуку інформації. 
Доступність значної кількості електронних статей, он-лайн бібліотечних баз даних, навчально-методичних вказівок, які викладено на сайтах медичних закладів, розширюють потенціал студентів, дозволяють аналізувати, проводити узагальнення і опрацьовувати дані [5, с. 68]. На сайті кафедри біологічна та медична хімія містяться методичні розробки для самостійної роботи студентів під час підготовки до практичного заняття I та II курсів на українській, російській та англійській мовах, які складаються викладачами на початку кожного навчального року. Студент-медик за допомогою даних матеріалів має можливість підготуватися до наступного заняття використовуючи Інтернет мережу та його ресурси, щоб отримати знання.

Таким чином, самостійна робота студента $\epsilon$ дуже важливою на сьогоднішній день, так як вона $є$ складовою частиною системи навчання у вищих навчальних закладах. Самостійна робота студента розвиває його творчу активність, критичне мислення, бажання постійно самовдосконалюватись, стимулює до постійного підвищення свого професійного рівня.

\section{Література:}

1. Калібабчук В.О., Зайцева Г.М., Галинська В.І., Лисенко Т.А. Медична хімія примірна програма навчальної дисципліни підготовки фахівців другого (магістерського) рівня вищої освіти. 2016. С. 1-28.

2. Закон України «Про вищу освіту» від 01.07.2014 // Відомості Верховної Ради (ВВР). 2014. № 1556-VII.

3. Киричок В.А. Компетентнісний підхід до організації самостійної роботи студентів вищих медичних (фармацевтичних) навчальних закладів. Вісник післядипломної освіти. Серія : Педагогічні науки. 2016. Вип. 1. С. 66-75.

4. Ярославцева К. В. Самостійна робота студента в процесі вивчення іноземної мови. Науковий вісник Ужгородського національного університету. Серія : Педагогіка, соиіальна робота. 2014. Вип. 30. C. 196-198.

5. Калібабчук В.О., Стучинська Н.В., Овчаренко В.Ю. Роль і місце електолнно-освітніх ресурсів у навчанні медичної хімії майбутніх лікарів. Науковий часопис НПУ ім. М.П. Драгоманова. Серія : Педагогічні науки: реалї та перспективи. 2013. Вип. 43. С. 68-74. 